\title{
Births at Home: About 411 Cases Collected in the Township of Hiheatro in the Southern Part of Togo
}

\author{
Baguilane Douaguibe ${ }^{1 *}$, Akila Bassowa'2, Dede Ajavon'3 , Bingo Kignomon M'Bortche1, \\ Tina Ayoko Ketevi', Francis Baramna-Bagou1, Komi Migbegna', \\ Abdoul Samadou Aboubakari³ ${ }^{3}$ Koffi Akpadza' ${ }^{1}$
}

${ }^{1}$ Department of Gynecology and Obstetrics, Sylvanus Olympio University Hospital Center, Lomé, Togo ${ }^{2}$ Department of Gynecology and Obstetrics, Campus University Hospital Center, Lomé, Togo ${ }^{3}$ Department of Gynecology and Obstetrics, Kara University Hospital Center, Lomé, Togo Email:^douaguibe@hotmail.com, akilabassowa@gmail.com,ddajavon@yahoo.fr, mbortche@yahoo.fr, tketevi@yahoo.fr, fbararmnabagou@gmail.com,martize07@gmail.com, anourislam@yahoo.fr,akpadza@yahoo.fr

How to cite this paper: Douaguibe, B., Bassowa, A., Ajavon, D., M’Bortche, B.K., Ketevi, T.A., Baramna-Bagou, F., Migbegna, K., Aboubakari, A.S. and Akpadza, K. (2021) Births at Home: About 411 Cases Collected in the Township of Hiheatro in the Southern Part of Togo. Open Journal of Obstetrics and Gynecology, 11, 1306-1316. https://doi.org/10.4236/ojog.2021.1110121

Received: August 23, 2021

Accepted: October 6, 2021

Published: October 9, 2021

Copyright (c) 2021 by author(s) and Scientific Research Publishing Inc. This work is licensed under the Creative Commons Attribution International License (CC BY 4.0).

http://creativecommons.org/licenses/by/4.0/ (c) (i) Open Access

\begin{abstract}
This was a cross-sectional and descriptive study conducted from January $2^{\text {nd }}$ to march $30^{\text {th }} 2019$ in the township of Hihéatro in Togo. We included in the study, women who had given birth at least once at home and who accepted to undergo the survey. Data were collected, using a pre-planned and pre-tested survey sheet, by a team of four trained interviewers under the responsibility of a supervisor. Interviews were carried out in the homes of the respondents after obtaining their informed consent. The parameters studied were the number of births at home, socio-demographic characteristics, and reasons for births at home and maternal and fetal prognosis. 411 women gave birth at home in the township. The average number of births at home per woman was 2 with extremes of 1 and 7 births per woman. The average age of the women was 28.4 years with the extremes of 15 and 38 years. The 25 - 34 age group represented $67.1 \%$ of cases. The average parity of the patients was 2. Multiparas represented $59.8 \%$ of cases. The main reasons for giving births at home by the interviewees were insufficient financial means in $36 \%$ of cases and the lack of means of transport in $28 \%$ of cases. Maternal morbidity was marked by $14.1 \%$ perineal tear, $1.6 \%$ hysterectomy. Four hundred and eleven newborns were registered. Of these newborns, $4.4 \%$ were stillborn and $8.8 \%$ did not cry at birth. Free obstetric care and increased awareness on the importance of assisted deliveries will improve the maternal-fetal prognosis.
\end{abstract}




\section{Keywords}

Childbirth, Home, Complications, Togo

\section{Introduction}

Home birth is any process of childbirth that takes place in the mother's home or any other home, whether the birth is attended by a skilled or unqualified health personnel, or simply a birth which does not occur under the supervision of a health personnel [1]. There are two types of out-of-hospital births: planned home births, which involve women who choose to give birth in their homes with the help of trained health personnel, and unannounced home births or delivery on the road where women enter in the active phase of labor in an unexpected way, resulting in an accidental delivery outside the hospital [2]. When home births are assisted by skilled health personnel, complications are minimized as shown in some studies [2] [3]. Home births without the assistance of qualified health personnel are a source of many complications that account for maternal and/or neonatal deaths [4] [5]. To improve maternal and neonatal mortality rates, childbirth should be attended by qualified health personnel, preferably in a health facility. In Togo, the maternal mortality rate is 401 deaths per 100,000 live births, the perinatal mortality rate is 27 per thousand and the birth rate assisted by skilled personnel is $59.3 \%$ [6]. These rates remain high despite the implementation of various policies to combat and reduce childbirthrelated deaths. Home births do not benefit from the assistance of health personnel in Togo. What can explain that women are still giving birth at home despite these various health policies? This study intends to answer this question by:

- Determining the number of home births.

- Describing the reasons for home births.

- Describing the maternal and fetal prognosis.

\section{Methodology}

The study was carried out in Hihéatro in 2019 in the southern part of Togo. Hihéatro is a township of the District of AMOU in which there are fourteen peripheral medical units, four Medico-Social centers and three Hospitals. Hihéatro is located at $26 \mathrm{~km}$ from Amlamé and $5 \mathrm{~km}$ from Atakpamé. This township has nine villages and a population of 15,748 inhabitants.

This was a cross-sectional and a descriptive study that was conducted from January $2^{\text {nd }}$ to march $30^{\text {th }} 2019$.

The study sample was randomized using a two-stage cluster survey (see Appendix). It is made up from the villages of the township of Hiéatro. All the villages were listed (nine villages) and each village was considered as a cluster. In 
each village, the concessions were drawn by lot. In drawn concessions, all women who fulfilled the inclusion criteria were interviewed.

The selection criteria

We included in the study

All the women who had given birth at least once at home and who gave their consent to undergo the survey.

All the women who had given birth at home, came to hospital for complications and gave their consent to undergo the survey.

Data was collected, using a pre-planned and pre-tested survey form, by a team of four trained interviewers under the responsibility of a supervisor. Interviews were carried out at the homes of the respondents after they have given their informed consent. The explanatory variable was the place of delivery. It was verified by the following question: who has experienced home delivery once or several times in his life? Any birth outside the approved maternity hospitals was considered as a home birth.

At the beginning of the investigation, the investigator reassured the respondents that the information they disclosed will remain anonymous and confidential. He then explained the rationale behind the study and the various data appearing on the investigation sheet. After this step, each interviewer interviewed the respondent in an environment that could guarantee the confidentiality and the privacy of the interviewee. The duration of the interview with each respondent varied from 30 to 45 minutes.

Data acquisition entry and tabulation operations were carried out using Epi info 6.0 software

Variables studied were:

- The frequency or number of home birth.

- The Socio-demographic characteristics: age, profession, level of education; marital status.

- History: gravidity, parity, prenatal follow-up.

- Process of the home birth: reasons, staff assisting the delivery.

- Maternal and fetal prognosis.

\section{Operational Definitions}

- Long "home-maternity" distance: when the distance separating the pregnant woman's home and the maternity ward is more than two kilometers.

- The lack of means of transport: when the pregnant woman's family does not have the means of transport to take her to the maternity ward.

- Insufficient financial means: insufficient financial means to pay the cost of transport by car and/or to pay the cost of medical care to be provided at the hospital (the amount is less than 15,000 CFA francs).

- Natural obstacle: when there is an obstacle that can prevent the parturient woman from reaching the maternity ward: a river separating the home from the maternity ward, the rainy season, late in the night. 


\section{Results}

\subsection{The Number of Home Births}

A total of 411 women gave birth at home in the District under study. The average number of home births per woman is 2 with extremes of 1 and 7 births per woman. In $55.7 \%$ of cases, there were at least two home deliveries per woman (Table 1 ).

\subsection{The Socio-Demographic Characteristics}

The average age of the women was 28.4 years with the extremes of 15 and 38 years. The 25 - 34 age group represented $67.1 \%$ of cases. The level of education of the women was as follows: primary education represented $39.2 \%$ and secondary education was $2.4 \%$ of cases. $58.4 \%$ of the women were illiterate. The main activity of the majority of the women was farming, representing 54.5\%. Thirty-five-point three percent of these women were retail sellers. The spouses of the women interviewed were farmers and life stock breeders representing respectively $67.4 \%$ and $11.2 \%$ of cases. The majority of women were married representing $92.7 \%$ of cases. $61.6 \%$ of them were Christians (Table 1 ).

The average parity of the patients was 2 . Multiparas representing $59.8 \%$ of the women (Table 2).

Prenatal medical follow-up was not carried out for women who gave birth at least three times at home in their life. They did not know whether the first two home deliveries were followed-up or not. Seventy-point six percent of those who gave birth at home for the first or second time had received at least one prenatal care. Out of these, $14.7 \%$ had undergone at least four antenatal consultations. Registered Midwives, birth attendants and permanent birth attendants were the health care personnel who provided prenatal care for these women.

\subsection{Reasons for Home Birth}

The lack of financial means was the main reason for giving birth at home (Table 3).

In this study, women who gave birth at home were most often assisted by their family members in $82 \%$ of cases, the traditional birth attendants in $13.6 \%$ of cases and those who gave birth without any assistance represent $4.4 \%$ of the cases.

Table 1. The socio-demographic characteristics of participants recruited from township of Hiheatro (Togo), from January $2^{\text {nd }}$ to march $30^{\text {th }}(\mathrm{N}=411)$.

\begin{tabular}{ccc}
\hline & Number & Pourcentage \\
\hline$[25-34$ YEARS $]$ & 276 & 67.2 \\
Illiterate & 240 & 58.4 \\
Primary school & 161 & 39.2 \\
Farmer & 224 & 54.5 \\
Maried & 381 & 92.7 \\
Christian & 253 & 61.6 \\
\hline
\end{tabular}




\subsection{Maternal and Neonatal Prognosis}

163 women were recorded representing $39.6 \%$ of the cases who had complications and were later admitted to health facility. Maternal morbidity reached $14.1 \%$ perineal tear, $1.6 \%$ hysterectomy. All the women with uterine rupture had undergone hysterectomy. Among those with anemia due to blood loss, 17 had been transfused (Table 4).

Four hundred and one births were registered. Out of these, $4.4 \%$ were stillbirths

Table 2. Number of home births of study participants recruited from township of Hiheatro (Togo), from January $2^{\text {nd }}$ to march $30^{\text {th }}(\mathrm{N}=411)$.

\begin{tabular}{ccc}
\hline & Number & Pourcentage \\
\hline 01 & 182 & 44.3 \\
02 & 131 & 31.9 \\
03 & 59 & 14.4 \\
04 & 21 & 5.1 \\
05 & 5 & 1.2 \\
06 & 5 & 1.2 \\
07 & 8 & 1.9 \\
TOTAL & 411 & 100.00 \\
\hline
\end{tabular}

Table 3. Reasons for home delivery of study participants recruited from township of Hiheatro (Togo), January $2^{\text {nd }}$ to march $30^{\text {th }}(\mathrm{N}=411)$.

\begin{tabular}{ccc}
\hline & Number & Pourcentage \\
\hline insufficient financial means & 148 & 36 \\
lack of means of transportation & 115 & 28 \\
Long "home-maternity" distance & 102 & 18.5 \\
Natural obstacle & 76 & 9.5
\end{tabular}

Table 4. Complications and morbidity during home deliveries of study participants recruited from township of Hiheatro (Togo), from January $2^{\text {nd }}$ to march $30^{\text {th }}(\mathrm{N}=411)$.

\begin{tabular}{ccc}
\hline & number & Pourcentage \\
\hline tears of the perineum & 58 & 14.1 \\
placental retention & 49 & 11.9 \\
delivery hemorrhages & 35 & 8.5 \\
Seizures after childbirth & 11 & 2.7 \\
uterine Rupture & 6 & 1.6 \\
Head retention & 4 & 1 \\
Anemia with transfusion & 17 & 4.1 \\
Hysterectomy & 6 & 1.6 \\
\hline
\end{tabular}


Table 5. Prognosis of the newborns of study participants recruited from township of Hiheatro (Togo), January $2^{\text {nd }}$ to march $30^{\text {th }}(\mathrm{N}=411)$.

\begin{tabular}{ccc}
\hline & number & Pourcentage \\
\hline Newborn alive crying immediately & 298 & 72.5 \\
Newborn alive crying out & 59 & 14.3 \\
Newborn alive not crying & 36 & 08.8 \\
Stillborn & 18 & 4.4 \\
Total & 411 & 100.0 \\
\hline
\end{tabular}

and $8.8 \%$ of the newborn did not cry at birth and have been admitted to the maternity hospital for resuscitation care (Table 5).

\section{Discussion}

\subsection{Number of Home Births and Sociodemographic Characteristics}

The average number of home births was 1.98 or two (2) home births with extremes of 1 and 7 home births. Having a baby once at home can sometimes be explained by the surprise of the labor. Having delivered at home on numerous occasions without the assistance of trained medical personnel may be an option for these women who consider pregnancy and childbirth as physiological processes; therefore, they may not need medical attention or outside intervention. This option is further reinforced by the age at which these deliveries occur as registered in this study. The average age of patients was 28.4 years and the age group of 25 - 34 years was the most represented to the level of $67.1 \%$ of cases. A mature woman's age should be an important factor in the discernment and the responsible decision-making. But in this study this was not the case.

The majority of the patients were already adults and are supposed to make responsible decisions. This behavior can probably be explained by the fact that these women do not always have the financial autonomy and were in most of the cases dependent on their husbands. The latter, given their limited means, can choose home delivery as an option for their wives. This can be explained by the fact that, in this study the main reason that pushed women to give birth at home was insufficient financial means. Another factor that can comfort women in this choice would be their experience of motherhood, because in this study, $59.8 \%$ of the patients were multiparous. Multiparity would lead some women to take the risk of giving birth at home. Several studies state that grand multiparas give birth mostly at home [7] [8] [9] [10] [11], since labor hours are generally noticeably reduced in multiparas. This could be explained by the fact that these women think that since they have had the experience of childbirth, they can do without a skilled health care provider. This mentality in the context of this study can be in part attributable to established societal norms and the low level of education of these women because in the society under study nearly $58.4 \%$ of women were illiterate. Schooling for young girls and awareness-raising actions alone can change the situation and 
help reduce the rate of morbidity and mortality due to unassisted childbirth as stipulated in the previous studies [4] [5] and [11]. Even if the humanization of childbirth brings women to childbirth everywhere, it is important that childbirth is attended by qualified medical personnel. Accompanied home birth would be an alternative to reduce the complications associated with unassisted home births.

\subsection{Reasons for Home Births}

The reasons that motivate women to give birth at home were insufficient financial means (36\%) of cases, lack of means of transport (28\%) of cases; the long "homematernity" distance $(24.8 \%)$ of cases, the natural obstacle (18.5\%), poor reception at the maternity wards (9.5\%) of cases. Diallo and Coulibally described the same reasons in Guinea and Mali. In Cameroon, it is the uneducated and poor populations of the north of the country who give birth at home [12] [13] and [14]. The lack of financial means is said to be related to their source of income. In this study, the main activity of the respondents was agriculture representing $54.5 \%$ of cases. Their spouses were farmers and livestock breeders representing respectively $67.4 \%$ and $11.2 \%$ of cases. Financial income is earned from the sale of farm products. These products are harvested by season and very often under the influence of bad weather. The good season does not always smile on everyone [12] [14].

As a result, women and their families were not always able to pay the cost of childbirth medical care in a maternity ward. The population has always considered child delivery at a health facility as a source of huge expenses. So it is only those who have financial means that give birth at a health facility. Women today must have the courage to give birth at home to avoid huge expenses for the in-laws. The availability of adequate means of transport for people was scarce in the villages. This finding is often due to the lack of the means of transport vehicles. As the villages are inaccessible to vehicles, a woman in labor should walk over a long distance before finding a transport vehicle, which turns out to be impossible overnight at times. The most available means of transport remains the two-wheeled motorcycle or the bicycle. Transporting a pregnant woman, especially in labor, is not easy and safe on a motorcycle or on a bicycle. The availability of a motorbike at the beginning of labor is not guaranteed and the risk taken by the woman and her child during the transport process makes the population opts for giving birth at home. The inaccessibility of a health center is often provoked by a natural cause such as a river or a mountain. People have to cross a river or climb a mountain before reaching a road on which they can find a means of transport. It is sometimes difficult to get around even on a motorcycle. Sometimes childbirth occurs in the process of the transport to a health center. The belief of the elderly people who feel that they have no problem with their children delivering at home.

\subsection{Maternal and Neonatal Prognosis}

The main complications observed in this study were tears of the perineum (14.1\%), 
placental retention (11.9\%), and delivery hemorrhages (8.5\%).

Maternal morbidity risk factors for placental retention and delivery hemorrhages were due to the lack of medical supervision during delivery and the lack of active management of the $3^{\text {rd }}$ phase of delivery. The same complications were observed by other authors in sub-Saharan Africa [12] [13] [14]. The results can be explained by the ignorance of the rules of the obstetrical art by unqualified persons who gave birth to parturient women. The tear of the perineum is related to the non-protection of the perineum and the absence of an episiotomy in its prevention.

Four hundred and eleven newborns were registered. Out of these newborns, $4.4 \%$ were stillborn and $8.8 \%$ did not cry at birth.

Assisted delivery allows the skilled attendant to monitor the labor, maternal condition, and fetal condition in order to make timely decisions. Home births under this context are not assisted by qualified medical personnel [12] [14]. This situation provokes a heavy toll on the fetus. Also, children who do not cry at birth can develop psychomotor retardation. A study on the fate of children born at home without the assistance of qualified medical personnel will make it possible to assess the real impact of these deliveries on the psychomotor development of children.

\section{Conclusion}

Home birth is a reality in Togo. The main reasons for this birthing option are based insufficient financial means, the lack of the means of transport, the long "home-maternity" distance, the natural obstacle, and the poor reception at the maternity wards where they exist. Free obstetric care and increased awareness on the importance of assisted childbirth will improve the maternal and fetal prognosis.

\section{Declarations}

\section{Ethics Approval and Consent to Participate}

This study was approved by the "Comité de Bioéthique pour la Recherche en Santé (CBRS)" (Bioethics Committee for Health Research) from the Togo Ministry of Health, Ref N0: 0101/2016/MS/CAB/DGS/DPLET/CBRS).

\section{Availability of Data and Materials}

Extracted data are with the authors and available for sharing on request.

\section{Authors Contributions}

Baguilane DOUAGUIBE was responsible for the conception of the study, participated in the study design, performed the surgery, and wrote the paper. Bingo Kignomon MBORTCHE, Tina Ayoko KETEVI, Akila BASSOWA, Dede AJAVON, Francis BAGOU-BARARMNA, Komi MIGBEGNA, Abdoul Samadou ABOUBAKARI were involved in the treatment and follow up of the patient; they have re- 
viewed the paper. They were responsible for the overall scientific management of the study and the preparation of the final paper. All the authors have read and approved the final paper to be submitted for publication.

\section{Conflicts of Interest}

The authors declare no conflicts of interest regarding the publication of this paper.

\section{References}

[1] Zur, M., Hadar, A., Sheiner, E. and Mazor, M. (2003) Out of Hospital Deliveries: Incidence, Obstetrical Characteristics, and Perinatal Outcome. Harefuah, 142, 38-41.

[2] Wiegers, T.A., Keirse, M.J., van der Zee, J. and Berghs, G.A. (1996) Outcome of Planned Home and Planned Hospital Births in Low Risk Pregnancies: Prospective Study in Mid-Wifery Practices in the Netherlands. BMJ, 313, 1309-1313. https://doi.org/10.1136/bmj.313.7068.1309

[3] Neuhaus, W., Piroth, C., Kiencke, P., et al. (2002) A Psychosocial Analysis of Women Planning Birth outside Hospital. Journal of Obstetrics and Gynaecology, 22, 143-149. https://doi.org/10.1080/01443610120113274

[4] da Silva, Z.P., de Almeida, M.F. and Pereira Alencar, G. (2014) Accidental NonHospital Birth as an Indicator of Risk of Infant Mortality. Revista Brasileira de Saúde Materno Infantil, 14, 235-239.

[5] Razafimanantsoa, E., Robillard, P.Y., Desveaux, C., et al. (2017) Accouchements inopinés à domicile ou "en route" dans le Sud de l'île de La Réunion: 656 naissances en 15 ans. Revue de Médecine Périnatale, 9, 37-46. https://doi.org/10.1007/s12611-017-0399-7

[6] Ministère de la Planification, du Développement et de l'Aménagement du Territoire (MPDAT), Ministère de la Santé (MS) et ICF International (2015) Enquête Démographique et de Santé au Togo 2013-2014. MPDAT, MS et ICF International, Rockville.

[7] Bi Vroh, J.B., Tiembré, I., Zengbé-Acray, P., et al. (2009) Prévalence et déterminants des accouchements à domicile dans deux quartiers précaires de la commune de Yopougon (Abidjan), Côte d'Ivoire. Dans Santé Publique, 21, 499-506. https://doi.org/10.3917/spub.095.0499

[8] Billon, M., Bagou, G., Gaucher, L., et al. (2016) Accouchement inopiné extrahospitalier: Prise en charge et facteur de risque. Journal de Gynécologie Obstétrique et Biologie de la Reproduction, 45, 285-290. https://doi.org/10.1016/j.jgyn.2015.04.001

[9] Nguyen, M.L., Lefèvre, P. and Dreyfus, M. (2015) Conséquences maternelles et néonatales des accouchements inopinés extrahospitaliers. Journal de Gynécologie Obstétrique et Biologie de la Reproduction, 45, 86-91. https://doi.org/10.1016/j.jgyn.2015.02.002

[10] Lukumar, P. and Pathmeswaran, A. (2006) Factors Associated with Home Deliveries in Thampalakamam, Trincomalee. Ceylon Medical Journal, 51, 59-62. https://doi.org/10.4038/cmj.v51i2.1354

[11] Ovaskainen, K., Ojala, R., Gissler, M., et al. (2015) Out-of-Hospital Deliveries Have Risen Involving Greater Neonatal Morbidity: Risk Factors in Out-of-Hospital Deliveries in One University Hospital Region in Finland. Acta Paediatrica, 104, 1248 1252. https://doi.org/10.1111/apa.13117

[12] Diallo, F.B., Diallo, T.S., Sylla, M., Onivogui, F., Diallo, M.C., Balde, Is. and Diallo, 
M.S. (1999) Problèmes médicaux et socio culturels de l'inadéquation entre les taux de consultations prénatales $(\mathrm{CPN})$ et d'accouchements assistes dans les 4 régions naturelles de la guinée. Médecine d'Afrique Noire, 46, 32-38.

[13] Coulibaly, S.K. Les accouchements non assistes dans le centre de sante de référence de la commune ii du district de Bamako étude cas/témoins l. Thèse de médecine année universitaire: 2009-2010 No....0345.

[14] Tchango, N.G.A.(2015) L'accouchement à domicile au Cameroun disparités spatiales et essai d'explication, 7 eme conférence africaine sur la population Johannesburg-dividende démographique en Afrique: Perspectives, opportunités et défis. Afrique Du Sud. 


\section{Appendix}

HEALTH SURVEY QUESTIONNAIRIES

Sheet $\mathrm{N}^{\circ} /$ I

'

\section{Identification}

- Education level / $/ 1=$ has left school. $\quad 2=$ No

- Age /

- Profession / / 1 = Housewife;

$2=$ other

- Marital status / $/ 1$ = Married; $\quad 2$ = Single; $3=$ Widower $; \quad 4=$ Divorced

- Religion / / 1 = Christian; 2 = Muslim; $3=$ A Pagan

\section{Personal Background}

Medical

- None: / __ I

- Diabetes: / _ _ / $(1=$ Yes; $2=$ No $)$

- HTA: / _ / $(1=$ Yes; 2 = No $)$

- Sickle cell disease: / _ _ / $(1=$ Yes; $2=$ No $)$

- HIV: / __ / ( 1 = Yes; 2 = No) Gynecology and obstetrics

- Gesture: / _ I

- Parity: /

- Number of living children: /

\section{Antenatal Consultation}

Not done: Done number

What are the paraclinical and imaging examinations that you performed during your pregnancy?

$\begin{array}{lll}\text { No? / _ / Ultrasound / _ / } & (1=\text { Yes; } & 2=\mathrm{No}) \\ \text { Rhesus grouping / _ / } & (1=\mathrm{Yes} ; & 2=\mathrm{No})\end{array}$

\section{Childbirth}

Where did you give birth? / _ _ / $\quad 1=$ At home; $\quad 2$ = Health Center If at home, what are the reasons: /

$1=$ Distance, $2=$ Lack of means of transport,

3 = Lack of financial means, $\quad 4=$ Natural obstacle (mountain, river)

Is it okay to give birth at home: / _ / / $(1=$ Yes; $\quad 2=$ No $)$

\section{Complications}

What complications did you have during your home delivery: / 1

$1=$ Injury to the soft parts of the mother,

$3=$ Placental retention,
$2=$ Neonatal distress, $4=$ Delivery haemorrhage 